\title{
Erratum to: Echocardiographic and Three-Dimensional Computed Tomographic Diagnosis of Crossed Pulmonary Arteries: Report of Three Cases
}

Kadir Babaoglu • Fatih Köksal Binnetoglu •

Gürkan Altun • Muhammed Dönmez •

Yonca Anık

Published online: 1 April 2010

(C) Springer Science+Business Media, LLC 2010

Erratum to: Pediatr Cardiol

DOI 10.1007/s00246-010-9664-2

Unfortunately the name of the fourth author was inadvertently misspelled in the original version. The name of the author should be Muhammed Dönmez.

The online version of the original article can be found under doi:10.1007/s00246-010-9664-2.

K. Babaoglu $(\bowtie) \cdot$ F. K. Binnetoglu · G. Altun Department of Pediatric Cardiology, Faculty of Medicine,

Kocaeli University, Kocaeli, Turkey

e-mail: babaogluk@yahoo.com

M. Dönmez · Y. Anık

Department of Radiology, Faculty of Medicine,

Kocaeli University, Kocaeli, Turkey 